\title{
The Promise of Co-Design for Public Policy
}

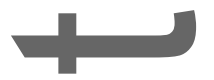

\section{Dr Emma Blomkamp}

The Policy Lab, School of Social and Political Sciences, The University of Melbourne, Parkville, VIC 3010, Australia.

ORCID ID: 0000-0003-0978-2830

\section{Acknowledgements}

This paper was developed further from presentations given in 2017 to the Australia New Zealand Public Policy Network in Adelaide and at the $3^{\text {rd }}$ International Conference on Public Policy in Singapore. The author would like to thank fellow conference participants and various reviewers, including Dr Lesley Pruitt, for their useful feedback.

\begin{abstract}
As a novel method for creatively engaging citizens and stakeholders to find solutions to complex problems, co-design holds great promise for policy-makers. It has been vaunted as a way to generate more innovative ideas, ensure policies and services match the needs of citizens, achieve economic efficiencies by improving responsiveness, foster cooperation and trust between different groups, meaningfully engage the 'hard to reach', and achieve support for change. This article considers how we might determine whether co-design has real potential to dramatically improve policy processes and outcomes. Drawing on relevant literature on participatory design, design thinking and public sector innovation, this review explores the meaning and potential of co-design in the context of public policy. It highlights the philosophical underpinnings and normative implications of participatory design, and questions the feasibility of achieving the promised outcomes in the challenging context of contemporary policy-making.
\end{abstract}

\section{Key words}

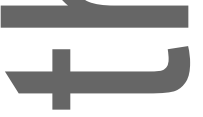

Policy design, co-design, participatory policymaking, design thinking, innovation

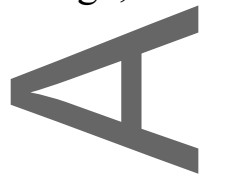

This is the author manuscript accepted for publication and has undergone full peer review but has not been through the copyediting, typesetting, pagination and proofreading process, which may lead to differences between this version and the Version of Record. Please cite this article as doi: $\underline{10.1111 / 1467-8500.12310 .}$.

This article is protected by copyright. All rights reserved. 


\section{Summary at a glance:}

Co-design is a promising approach that offers creative and participatory methods for engaging different kinds of people and knowledge in the policy process. More documentation, analysis and evaluation are nonetheless required to determine the extent to which co-design can meet its innovative and transformative potential in policy-making.

\section{Main text - Introduction}

On a cold morning in 2015, a small group of casually attired public sector workers gathered in a run-down building in South Auckland, New Zealand. Surrounded by walls plastered in colourful sticky notes, the co-design team warmed up over cups of tea and through a creative ice-breaker activity. Local families, predominantly from indigenous (Māori) and Pacific Island cultures, began arriving for interviews, in which they would share their attitudes to and experiences of driver licensing. These interviews helped the team build empathy with, and understand the perspectives of, people who were struggling to navigate and follow New Zealand's graduated driver licensing system. Over the following weeks, the team would compare, analyse and synthesise the data from this ethnographic design research to build up a picture of the licensing system from the perspective of these 'end users'. The insights and issues they identified would later be used to challenge and inspire a wide range of people to come up with ideas to improve the system. After these ideas had been tested with more end users, the preferred concepts were presented in a 'case for change', which made recommendations to key stakeholders in government to implement different policies and services in order to result in more people driving legally (Auckland Co-Design Lab 2016).

This vignette of the work of the Driver Licensing Challenge from the Auckland Co-Design Lab provides a tangible example of the practice of co-design in the public sector. Funded by New Zealand's central government and hosted by the country's largest local government, the Auckland Co-Design Lab was established to provide a 'neutral space' for multi-agency teams 
'to explore the use of co-design and other innovative approaches to address complex social issues' (Auckland Co-Design Lab 2015). It offers one of many examples of co-design being used to effect change in a governmental context.

Many claims about the need for and benefits of co-design in the public sector have been made recently, particularly by innovation units, consultants, and as part of reform processes in Australia and Ney Zealand. Co-design is often framed as a new or different way to address longstanding social challenges that the public sector is failing to address. It has been put forth as a promising approach to improve public policies and government services in discussions of citizen participation in the Australian Government's policy process (Holmes 2011; Lenihan and Briggs 2011; DIIS 2017) and as part of the New Zealand Government's Policy Project (Government Economics Network 2016), as well as by other public sector agencies (e.g. Evans 2012; DHHS 2016). In addition to the Auckland Co-Design Lab described above, co-design was a keyingredient in DesignGov, the Australian Government's 18-month pilot initiative 'to demonstrate the value of design-led innovation' (Treadwell 2013). Co-design is also a key plank in the Victorian State Government's 10-year plan to address family violence, which promises: All of these reforms will be designed and delivered in partnership with the Victorian community' (Department of Premier and Cabinet 2016, ix). Consequently, 'statewide co-design' and 'local co-design processes' are being carried out to shape the development of a network of Support and Safety Hubs, whereby co-design is being used to ensure that the hubs are 'implemented and informed by local context, delivering services relevant to local needs' (State Government of Victoria 2017). The term co-design is increasingly common in government discourse like this, yet a clear and shared definition is lacking. Like co-production, co-design has been 'granted an influential role in the future of ... public governance on the basis of little formal evidence' (Durose et al. 2017, 137). Consequently, co-design risks being little more than a buzzword in the public sector. This article addresses confusion around the

This article is protected by copyright. All rights reserved. 
meaning of the term, sets forth a comprehensive definition, and identifies associated concepts and relevant literature for further exploration. It also raises questions about the appropriateness of available evidence to support the claims being made about the benefits of co-design.

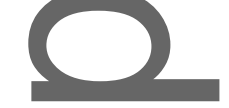

This analysis is based on a review of literature that discusses co-design practice in the context of government policy and services. In part because there are few academic articles specifically on co-design for public policy, but also because of the importance of developing a practice-based understanding, this review draws extensively on 'grey' literature, including presentations, blogs, discussion papers and reports produced by design consultants, non-governmental organisations and public sector departments. It is also informed by scholarly literature on design-for-policy, public sector innovation, design research and policy sciences. While academic and practice-based accounts of human-centred design and co-design in the public sector typically focus on service design, this article concentrates on the unique context of policy design in Australia and New Zealand. It is beyond its scope to review the full body of literature on participatory and community-based models of planning, democracy, development and governance; nonetheless, the author acknowledges these important antecedents and related concepts. From this perspective, co-design is not entirely new - it draws on established traditions of participation, collaboration and empowerment in public policy and planning. Yet the unique combination of these features within an innovation process, involving principles and tools from the field of design, distinguishes co-design for policy from traditional approaches in the aforementioned disciplines. Responding to some conflation and confusion of terms in praetice, this paper carefully elucidates distinctions between co-design and several commonly associated approaches.

The review opens by putting forth a definition of co-design as a methodology for This article is protected by copyright. All rights reserved. 
policy-making. Breaking it down into a process, principles and practical tools allows us to consider its philosophical underpinnings, implicit goals and related concepts. The article then outlines challenges that question the feasibility of achieving these outcomes in the contemporary context of policy-making. These risks and potential limitations are likely to be of particular interest to practitioners and public sector managers. Finally, recognising the growing interest in the emerging discourse and practice of co-design in public policy contexts, it sketches potential directions for future research.

\section{(}

\section{Towards a definition of co-design for policy}

For specialist praetitioners, co-design is a distinct set of principles and practices for understanding problems and generating solutions. It signifies the active involvement of a diverse range of participants in exploring, developing and testing responses to shared challenges. In the public sector, co-design is often invoked as a more effective, democratic or innovative alternative to conventional approaches to community engagement, public participation, service design and policy development. Many definitions and synonyms appear in discussions of co-design, which can make it difficult to pinpoint examples of practice or evaluate their impacts. When co-design is loosely defined and operationalised as any type of collaborative or participatory activity, almost everyone seems to be doing it. For instance, of the 466 respondents to an international PwC survey of public service workers, more than 90 per cent reported being involved in a 'co-design' project that included service users in the design or development of a service (Bradwell and Marr 2008, 35). The Demos report on the survey results acknowledges that it would be 'legitimate to ask whether the processes described by respondents really involve in-depth collaboration, or whether they betray more minimal, customer-service approaches.' (Bradwell and Marr 2008, 38). Highlighting the difference 
between such approaches, this article argues that only the former should be described as co-design.

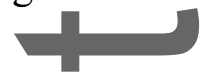

A simple way to understand the term co-design is to break it down into its constitutive parts. The 'co' is typically considered an abbreviation for 'cooperative' or 'collaborative' design, which draws on the Scandinavian tradition of participatory design (Steen, Manschot, and De Koning 2011, 53; Burkett 2012, 6; Torjman 2012, 19). Participatory design methods emerged out of user involvement in workplace and software systems design nearly 40 years ago, and co-design continues to be an important approach in information and communications technologies today (Sanders 2014, 61-62; Kimbell 2015, 65). Within built environment governance, the traditions of participatory planning and community design can similarly be traced back to the 1960s (Sanoff 1990). Like the concepts of 'user-centred innovation' and 'co-creation', the notion of co-design comes largely from private sector innovation literature, but '[has] been increasingly applied within public services' (Farr 2013, 447). 'Design' in this sense draws on the discipline of industrial design, rather than the traditionally broad conceptualisation of 'policy design' in political studies literature - as a problem solving process that configures a pattern of action in order to achieve a specific governmental outcome (O'Rafferty, de Eyto, and Lewis 2016, 2). The growing interest in co-design follows the broader proliferation of 'design thinking' throughout the private and public sectors, as principles and methods from design and related fields have been taken up by other sectors (Brown and Wyatt 2010; Mintrom and Luetjens 2016).

A shared definition of co-design that is appropriate for governmental contexts is needed in order to advance practice and research in this domain. An appropriate definition of co-design as a methodology for policy-making would recognise it as a design-led process, involving

This article is protected by copyright. All rights reserved. 
creative and participatory principles and tools to engage different kinds of people and knowledge in public problem-solving. Co-design for policy thus has three key components process, principles and practical tools (see Table 1) - each of which are discussed in turn below. This understanding is based on both academic and practitioner accounts of co-design, and resembles Elizabeth Sanders' (2014) description of co-design as method, mindset and tools. The definition proposed here has been adapted specifically for the context of public administration

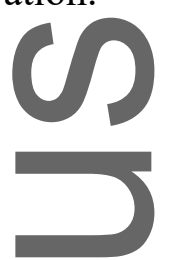

Table 1. Key components of co-design for policy

\begin{tabular}{|l|l|}
\hline Process & Iterative stages of design thinking, oriented towards innovation \\
\hline Principles & $\begin{array}{l}\text { People are creative; people are experts in their own lives; policy } \\
\text { should be designed by people with relevant lived experience }\end{array}$ \\
\hline Practical tools & Creative and tangible methods for telling, enacting and making. \\
\hline
\end{tabular}

Co-design is a design-led process. There are many iterations of 'design thinking' and design-led innovation models in use among private, public and community organisations around the world. Design thinking can be summed up as an iterative, human-centred and action-oriented process for innovation (Cohen 2014). In more scholarly terms, design thinking has been defined as the application of abductive reasoning to reframe an unstable problem situation and create a new object, service or system (Dorst 2010). These definitions and associated models of 'design thinking' attempt to codify design processes so that non-designers can understand and use them. One of the most well-known models is the 'Double Diamond', developed by the UK Design Council (2007) based on research with eleven international companies, and which aims to visually represent common phases in the This article is protected by copyright. All rights reserved. 
process of design. Common features of design-based models include iterative stages of divergence and convergence (going wide then getting focused), within a series of phases starting with 'discovery' or 'inspiration', leading to 'design' or 'ideation', and followed by ‘delivery' or 'implementation' (see, e.g. IDEO, n.d.; Evans and Terrey 2016, 246). As with the policy cycle (see, e.g., Colebatch 2005), in practice this process is not so linear or sequential. Moreover, the dominant problem-solving and action-oriented models of design can be critiqued for the monocultural (Eurocentric) and neoliberal values that are embedded within them (Akama 2018).

Defining co-design as a design-led process is nonetheless important, as it indicates that it is a methodology for innovation. It is about generating and testing new solutions to public problems, not merely offering creative approaches to consultation or 'co-production' at the stage of delivery. Co-design thus challenges conventional approaches to planning and policy-making, as it requires wide input into problem definition and the development of solutions, rather than merely offering the opportunity for citizen or stakeholder feedback once a policy or plan has been formulated by specialist professionals (Al-Kodmany 2001, 118). Moreover, it recognises that 'the process is continuous and ever changing', which has implications for policy designers whose job is 'no longer to produce finished and unalterable solutions' but to continuously co-create and negotiate solutions with people affected by policy issues (Sanoff 1990, 7).

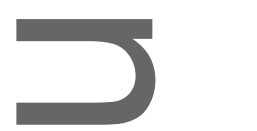

Co-design follows the principles of participatory design. A distinguishing feature of co-design is the philosophy that underpins it, based on the radical roots of participatory design. As Sanoff $(1990, \mathrm{i})$ explains, 'This approach is based on the democratic concept whereby people affected by design decisions should be involved in the process of making the decisions.' 
Applied to policy, this means enabling or empowering the people affected by a policy issue to actively contribute to developing a solution for it. Co-design thus aligns normatively with community-driven development and deliberative democracy, which also seek to enhance citizen participation and empowerment (Evans and Terrey 2016, 244). Co-design practitioners and guides often talk about these principles as a 'mindset'. Sanders (2008), for instance, distinguishes between a 'participatory mindset' and 'expert mindset'. The participatory mindset is based upon egalitarianism (Sanoff 1990, 1), a 'belief that all people are creative' (Naranjo-Bock 2012), and a 'faith' that every individual has 'the capacity to participate in and direct change in their lives' (Burkett 2012, 8). As 'experts in their own experiences,' citizens and stakeholders should be involved in designing services and policies that relate to those experiences (Cabinet Office 2017).

\section{(1)}

Lived experience is thus treated as a type of expertise in participatory design, challenging the usual privileged position of external experts in policy advisory systems (Howlett and Migone 2013) and the traditional "big-ego design" approach in which gifted individuals impose their 'design expert's vision and ideas as if they were the only possible solution' (Manzini 2015, 66). Like the role of the designer in a design charrette (an established approach to co-design in urban planning), the policy-maker taking a co-design approach 'swaps from a prima donna role to a more serving and/or facilitating role' (Roggema 2014, 20). This need not mean a loss of scientific evidence or professional expertise; rather an 'additive' co-design approach can bring formal evidence together with local knowledge and experiential expertise (Durose and Richardson 2016,41). If people with local knowledge and lived experience are not actively involved in the design process, but emphasis is put on their views and experiences, the process could be described as user-centred or human-centred design. It is only co-design if people who are affected by the issue are active participants in the design process.

This article is protected by copyright. All rights reserved. 
Co-design uses practical tools to enable participation and to access, generate and test experiences and ideas. While co-design is more than a 'toolkit', the visual and tangible methods that it offers are one of its key characteristics. Effective communications media, mapping and other visualisation tools are, in particular, recognised in the participatory planning literature as essential for facilitating citizen participation (Sanoff 1990, 7; Al-Kodmany 2001; King et al. 1989; Roggema 2014). According to Sanders (2014), there are three main types of techniques for co-design: telling, enacting and making. Using these techniques can provide rich evidence of 'real rather than assumed behaviours' (O'Rafferty, de Eyto, and Lewis 2016,15 ) and of tacit knowledge that is ingrained in people's everyday experiences. Methods such as diaries, collages, card sorts, model-building, and various forms of mapping and role playing can help to reveal knowledge that is non-verbal, holistic, non-linear, emotional or intuitive, and which may not be uncovered by other methods (Akama and Prendiville 2016, 31-34; Sanders 2014). This is different from deliberative approaches to policy-making, which focus on telling, and include very little enacting or making. Co-design does not subscribe to the deliberative policy-making ideals of communicative rationality and discourse ethics, which assume that policy problems can be solved through an open, rational and cognitive discussion (Gottweis 2007, 238-39; Mclaverty and Halpin 2008).

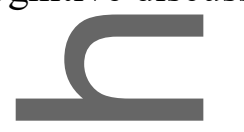

Although they may be creative experts in their own lives, many people are likely to need support or facilitation to express themselves and meaningfully participate in co-design. An important part of the co-design process is having a skilled facilitator who can choose the most appropriate tools to enable people to communicate and engage with each other, as well as feel comfortable and inspired enough to envision their own and others' ideas (Al-Kodmany 2001, 126; Sanders and Stappers 2008, 12). Some tools come from commercial design disciplines;

This article is protected by copyright. All rights reserved. 
others may draw on methodologies from, for example, community engagement and systems thinking. Design is seen as offering particularly powerful tools for collective creativity, especially by visualising complex ideas and flattening hierarchies (Katz, cited in Service Design Network 2016, 84; Kimbell 2015; Sanders 2014).

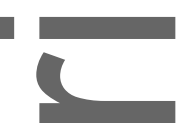

The creatiye techniques of co-design can help to generate and test ideas as rapidly and pragmatically as possible. Prototyping is an important stage of co-design, and embodies the features of co-design as process, principles and practical tools. Prototyping is a quick, low cost way to test an idea (or aspect of it) by creating an early sample or model and eliciting rapid feedback on it. The sample or model might be made out of paper or plasticine, role-played or shown on video. The objective is to receive immediate feedback from existing or potential users in order to refine or discard the idea. For example, as part of an initiative to improve outcomes for older Australians in private rental accommodation, the Australian Centre for Social Innovation(TACSI 2017) developed paper prototypes to explore policy options. They created visual representations contrasting 12 current and desired clauses in residential tenancy law, such as images depicting increased security of tenure or increased ability for personal expression in the home, to rapidly elicit feedback from citizens and stakeholders. They also developed scenarios based on their insights drawing on 'the lived experience of baby boomers', using toy figurines, sticky notes and other props, to walk through the implications of policy changes (Burkett 2016). These prototypes functioned as 'learning devices' (Burkett 2016). They illustrate the use of prototyping in policy design to: materialise interactions in complex systems; imagine alternative futures; and bring together different types of participants and forms of knowledge, especially to anticipate responses to policy issues and designs (Kimbell and Bailey 2017). Prototyping has hence been described as a 'design experiment', which "claims to provide an evidence base about "what works" in the early stages of the 
development of an intervention;' and which may also 'provide a staging post for a broader and more generalisable test in the future.' (Evans and Terrey 2016, 248).

Various comparisons have been made in the elaborated definition above, illustrating the difference between co-design and related but distinct approaches, such as human-centred design and co-production. Table 2 more explicitly distinguishes between these concepts to highlight what is unique and distinctive about co-design for policy.

\section{(}

Table 2. Similar (but distinct) approaches to co-design

\begin{tabular}{|c|c|}
\hline \begin{tabular}{l|l} 
Name of & Definition \\
approach &
\end{tabular} & $\begin{array}{l}\text { Key difference(s) from } \\
\text { co-design }\end{array}$ \\
\hline \begin{tabular}{l|l} 
Community & $\begin{array}{l}\text { Proactively seeking community values, } \\
\text { engagement } \\
\text { concerns and aspirations, in order to } \\
\text { incorporate them into decision-making } \\
\text { (Moore et al. 2016). }\end{array}$
\end{tabular} & $\begin{array}{l}\text { Does not necessarily follow } \\
\text { a design-led process, lead to } \\
\text { innovation, or involve } \\
\text { creative methods. }\end{array}$ \\
\hline \begin{tabular}{l|l} 
Co-production & A partnership approach to the delivery of \\
& public services, sometimes encompassing \\
the whole policy process (from design to \\
implementation) (Bracci, Fugini, and \\
Sicilia 2016, 7).
\end{tabular} & $\begin{array}{l}\text { Not necessarily involving a } \\
\text { design or development } \\
\text { process, or creative methods } \\
\text { - may focus solely on } \\
\text { implementation. }\end{array}$ \\
\hline $\begin{array}{l}\text { A form of democratic government in } \\
\text { which citizens have ample opportunity to } \\
\text { make decisions about public policy } \\
\text { (Bevir 2009, 130). }\end{array}$ & $\begin{array}{l}\text { Stronger emphasis on ideals } \\
\text { of self-rule and } \\
\text { self-determination; not } \\
\text { necessarily involving a } \\
\text { design-led process or } \\
\text { creative methods. }\end{array}$ \\
\hline $\begin{array}{l}\text { A form of democratic government based } \\
\text { on the unconstrained exchange of } \\
\text { arguments and reasoned discussion } \\
\text { (Cooke 2000, 947-48) }\end{array}$ & $\begin{array}{l}\text { Strong emphasis on rational } \\
\text { dialogue and practical } \\
\text { reasoning, rather than } \\
\text { design thinking, creativity } \\
\text { and abductive reasoning. }\end{array}$ \\
\hline
\end{tabular}

This article is protected by copyright. All rights reserved. 


\begin{tabular}{|c|c|c|}
\hline $\begin{array}{l}\text { Human-centred } \\
\text { design }\end{array}$ & $\begin{array}{l}\text { A contextualised design-led methodology } \\
\text { that incorporates end users' needs and } \\
\text { aspirations, and that involves citizens and } \\
\text { other stakeholders in the design process in } \\
\text { different ways (van der Bijl-Brouwer } \\
\text { 2016) }\end{array}$ & $\begin{array}{l}\text { Users, citizens or } \\
\text { stakeholders may be } \\
\text { minimally or passively } \\
\text { involved in the design } \\
\text { process, and do not } \\
\text { necessarily contribute to the } \\
\text { development of solutions. }\end{array}$ \\
\hline
\end{tabular}

\section{Claims about the benefits of co-design}

Many claims are being made by public servants, scholars and consultants about the benefits of applying do-design in the public sector. In particular, co-design is seen to improve idea generation, service delivery, project management and longer-term outcomes (Steen, Manschot, and De Koning 2011; DHHS and Peer Academy 2016, 11). These claims are predominantly framed in the context of product and service design, but they are often extended to policy design. The unique features of government and policy-making may mean that evidence and best practice from other sectors is not applicable or transferable, though. And while co-design may have transformative effects, many of the claims about its benefits have not been rigorously evaluated.In their peer-reviewed article on the benefits of co-design, for instance, Steen and colleagues (2011) do not describe the methodology of their literature review. Some of their key sources are little more than pamphlets published by the UK Design Council advocating for a particular approach, and providing little to no research evidence to substantiate their analysis. The plethora of grey literature on public and social design labs is also full of unsubstantiated claims (see McGann, Blomkamp, and Lewis forthcoming; Kieboom 2014, 17-19), and to date there is a lack of research critically examining these assertions. Explanations for the weak evidence base surrounding co-production could equally apply to that of co-design: 'its elasticity as a term' and the lack of appreciation for qualitative and case study research methodologies (Durose et al. 2017, 136).

This article is protected by copyright. All rights reserved. 
The lack of documentation and published evaluations of co-design approaches in public administration and policy limits knowledge sharing and evidence building. There is nonetheless evidence from some other fields, including healthcare, urban planning and the private sector, about the impacts of using co-design methodology. Some findings from evaluations of the design of public services may be particularly relevant for policy contexts. Healthcare co-design experiments, for example, have shown that applying a participatory design approach to improve the patient experience, specifically by reducing patient waiting time in Emergency Departments, has increased efficiency across the health system in the UK and Australia (Frontier Economics 2013; Piper et al. 2012). Academic analysis of 'experience-based co-design' approaches suggests that this consistently staged model of co-design has contributed to improvements in both operational efficiency and the inter-personal dynamics of care in hospital settings (Donetto et al. 2015; Larkin, Boden, and Newton 2015; Eocock et al. 2014; Palmer et al. 2015; Piper et al. 2012). Its emphasis on 'user participation' has been considered particularly valuable for government and administrators to receive feedback through 'co-learning, active collaboration, shared power and decision-making, resulting in service quality improvement (Palmer et al., 2015).

As well as considering the evidence from studies of service design and experience-based co-design in healthcare, literature that focuses on the benefits of citizen participation in policy, planning and governance is also pertinent. It reveals strong instrumental and normative arguments in support of citizen participation in policy-making. From an instrumental standpoint, democratic governments fail to effectively apply conventional policy tools, such as regulation, to complex and contested problems, especially when the public is distrustful of governments or elites (MacArthur 2016, 634; Fischer 2009). Involving citizens in designing 
and delivering public policy and services may increase quality and effectiveness. Citizens may possess relevant local knowledge and contribute novel ideas because they are not burdened by professional expertise or acculturated to business-as-usual approaches (Fung 2006, 73; Reich et al. 1996). Normative arguments, on the other hand, take issue with the domination of elites in policy, andsee participatory mechanisms as an opportunity to strengthen 'the depth and quality of a democracy'(MacArthur 2016, 634). There is a lack of empirical research, however, that assesses the impacts of involving citizens and other stakeholders in the design and delivery of public policy and services (Voorberg, Bekkers, and Tummers 2015). Consequently, as Burkett $(2012,5)$ notes, there is little evidence about whether participation by more people, or deeper participation by a few key people, is more effective.' Co-design practice in the public sector needs to be examined more closely and critically, with particular attention paid to 'who participates' (Fung 2006) and to configurations of power. This would help to understand which 'publics' are being engaged or excluded by current practices, and to explore their political and social implications, including any possible negative effects of participation (Donetto et al. 2015; Reich et al. 1996).

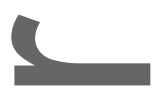

Despite the lack of evidence of the benefits of co-design for policy-making, this review has identified three plausible hypotheses that warrant further investigation. Firstly, the involvement of different types of participants (citizens, 'end users', stakeholders, professionals and experts) throughout the design process should mean that the definition of problems and generation of solutions better meet the needs of the public and the government. This would likely lead to improved efficacy and efficiency of policy and services. By ensuring that public policy better meets the needs of citizens and stakeholders, co-design may thus help to pre-empt future problems, especially by overcoming the common problem of policy interventions being based on flawed assumptions (O'Rafferty, de Eyto, and Lewis 2016, 15; Bradwell and Marr 
2008, 13-15; Lenihan and Briggs 2011). Secondly, offering methods and principles for improving idea generation and experimentation should stimulate innovation within the public sector (Bradwell and Marr 2008, 14; All, Van Looy, and Castellar 2013). This follows the argument in favour of design thinking, initially seen in the private sector, 'where it is generally recognised that the quality of design improves the more user interests are integrated into the design process' (Brown, cited in Evans and Terrey 2016, 245). Finally, if participants in the co-design process are likely to strengthen relationships and build trust and mutual understanding, then co-design may indeed build social capital and address disengagement and low trust in government.

This last point on the social value of co-design is particularly important in the context of public policy. Co-design, it has been suggested, 'creates a feeling of involvement and ownership' (Bradwell and Marr 2008, 15), by generating 'a shared understanding and shared language between participants and designers' and by supporting 'a sense of immersion, dialogue and empathy for the perspective of those who will use and experience the design' (Hagen and Rowland 2011). If effective, it therefore offers an approach for addressing disengagement from politics and democracy, by enhancing trust in and positive engagement between policy workers, citizens and other stakeholders (Bradwell and Marr 2008, 10, 14; Durose and Richardson 2016). Case studies and other practice-informed analyses have shown potentially transformative results for participants in co-design projects. Participation in planning-related design decisions is seen to increase participants' sense of agency, responsibility, and sense of connection to place, community and society (Sanoff 1990; King et al. 1989). By bringing diverse people together and helping them to forge meaningful connections, co-design has contributed to creating social relations (Akama and Prendiville 2016, 34) and building social capital (Bradwell and Marr 2008, 10). Effective facilitation of co-design and trusted 
relationships between participants and facilitators can lead to a constructive, action-oriented and future-focused dialogue to develop new policy directions (Howell and Wilkinson 2016, make (Akama and Prendiville 2016, 37-38). It is unclear to what extent these benefits are achieved in practice, if at all, beyond the individual case studies discussed in the literature. There is a need for greater investigation into the process and outcomes of co-design practice in the context of public policy and administration.

\section{(}

The challenges of co-design for policy

In addition to conceptual confusion, many practical challenges and risks await those applying co-design in a governmental context. The first significant risk identified by Steen et al. (2011, 59 ) is 'diminished control over the project, because other people, other departments or other organizations are involved.' Secondly, there may be challenges relating to the 'increased complexity of the project, because the objectives and interests of diverse people, departments or other organizations must be managed and balanced, which can require extra coordination efforts'. Indeed, the literature on experience-based co-design (cited above) commonly highlights its time-consuming nature, although it has been suggested elsewhere that the short-term costs of participatory design are likely outweighed by the long-term benefits (Reich et al. 1996,171). O'Rafferty and colleagues $(2016,14-15)$ also identify a number of challenges through their design research on environmental policy in Ireland. Relevant 'dilemmas of co-design' for public policy that they describe include: the gap between co-design research and conventionat forms of evidence; legitimacy of co-design activity as perceived by stakeholders and beneficiaries; and the embeddedness of the activity within the policy innovation system.

This article is protected by copyright. All rights reserved. 
Examples of co-design in practice are often limited to an early phase in the policy-making process. The UK Cabinet Office (2017) notes, for instance, 'Co-design can work at any point in policy design, however it is most commonly used at the beginning of a policy to help understand where a policy needs to focus.' Indeed, half of the public sector workers surveyed by $\mathrm{PwC}$ reported using co-design only at the beginning of the design process (Bradwell and Marr 2008,35) Implementation poses a particular challenge for co-design projects, especially when a small number of people have participated in creating a solution that will require significant buy-in and investment to put in place. Co-design typically happens with small, site-specific groups, and it is not obvious how participation and solutions can be scaled into system-wide responses with multiple delivery channels in large organisations (Bradwell and Marr 2008, 39-40; Farr 2013). This is especially challenging given 'the complexities of modern organized bureaucracies, networks, democratic mechanisms, and systems of resource allocation' (Chen et al. 2016, 3). It is questionable whether co-design can even be scaled up in this way. Design researchers Akama and Prendiville (2016, 37), for instance, argue that co-design 'needs to be firmly rooted in its location, time and people' so that it can progress 'organically from rich engagements and deep interactions over time.' Recent research on public sector innovation labs that take a design-led approach has similarly suggested that they may be better suited to 'singular programs, projects or services' as they struggle with 'higher level policy change' (Tonurist, Kattel, and Lember 2015, 20; see also Bason and Schneider 2014, 34-39).

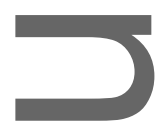

A significant challenge reported by co-design practitioners attempting to apply their craft within the public sector is that the structure and culture of government is not well suited to co-design. Policy officials do not generally respond well to the risks of diminished control and increased complexity, and bureaucratic systems are not designed to be experimental or responsive. Since politicians and 
government officials typically view themselves as 'sovereign decision-makers' who possess the mandate to rule for the people, rather than with the people, collaborative policy design may be unattractive to them (Ansell, Sørensen, and Torfing 2017, 479). This tension was illustrated in recent criticism of the Vietorian State Government for failing to understand how to work with communities and only ever asking for input once big decisions had already been made, even when it claimed to be 'co-designing' solutions (Donaldson 2017).

There are political and practical implications in the way that co-design challenges and disrupts established approaches to policy-making and to 'dominant public sector cultures and values' (Evans and Terrey 2016,260). Co-design, explains Burkett $(2012,7)$, 'involves a shift in the locus of responsibility and control so that "clients" or users of services become active partners in designing, shaping and resourcing services, rather than being passive recipients of pre-determined services'. As Bradwell and Marr $(2008,37)$ note, 'Commitment to participation requires a real willingness on behalf of those who have power to share it'. Currently, however - at least in the context of environmental policy in Ireland - 'the competencies and mind-sets required for co-design are not typically found within the public sector organisations' (O’Rafferty, de Eyto, and Lewis 2016, 15). Effectively applying co-design in the public sector will require significant cultural change and capacity building to embed 'all kinds of new knowledge, structures, and practices' (Lenihan and Briggs 2011, 46; Christiansen 2016). Embedding design into government is not just about upskilling policy workers on designerly methods, but also about bringing other disciplinary knowledge into the design process, and will likely require cultural and structural change to enable different approaches to be applied.

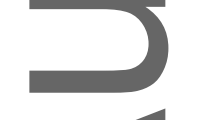

There are a number of methodological concerns too, particularly around the need to tailor co-design processes and enable meaningful participation. For co-design projects to be effective, the methods and tools need to be carefully selected and appropriately applied to each 
project (Steen, Manschot, and De Koning 2011, 59). Particularly careful consideration needs to be given to the means for involving citizens, users or stakeholders in co-design activities. 'Merely opening up possibilities for choice and participation' is not enough, notes Burkett
participate effectively in co-designing services.' Shared responsibility and trust between citizens and government are also prerequisites of co-design for policy (Durose and Richardson 2016, 35). A particular challenge, which may be inevitable in some government-led or initiated projects, arises when participants feel resentment or distrust towards a key project partner or sponsor (DMA 2015). This may be an increasing issue, given the already declining levels of trust in government and public institutions (Edelman 2017; Foa and Mounk 2016). The literature on participatory policy-making reveals the risks of co-optation and deepening cynicism if participatory projects are poorly designed, inadequately facilitated, or outright manipulative (see, e.g., MacArthur 2016, 637-38). Some recent articles on participatory urban planning indeed argue that co-design processes are subject to co-option by neoliberal forces and that participants risk being coerced and given a false sense of agency while legitimising the political agendas of elites (Kaethler, Blust, and Devos 2017; Palmås and Busch 2015).

Similarly co-production in the United States has been critiqued for co-opting and 'responsibilising' citizens in the state's quest for efficiency and governing at a distance (Durose and Richardson 2016, 36-37).

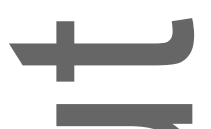

The potential risks, questionable benefits and inevitable challenges of applying co-design in governmental contexts raise all kinds of issues for further research. While it remains an emerging field, public sector co-design practice is beginning to mature enough to ask questions like, 'What kind of co-design works, and where?' (Bradwell and Marr 2008, 11). To paraphrase Burkett $(2012,5)$ - who notes 'the million dollar question' is that of social impact - 'Does involving and engaging people in This article is protected by copyright. All rights reserved. 
developing, designing and delivering [policy] actually create better [policy] and thus lead to great social impacts?' A more nuanced analysis of participation is needed to understand the efficacy and politics of co-design. Documenting and learning from co-design projects will help to understand when participation is appropriate and how it can be extended (Reich et al. 1996). Following Fung (2006, 67), we could ask, 'Who participates? How do they communicate and make decisions? What is the connection between their conclusions and opinions on one hand and public policy and action on the other?' In answering those questions, we could seek to understand whether and, if so, how co-design processes actively seek and effectively integrate a diverse range of views. Evidence from the already cited international survey of co-design in the public sector suggests they often do not do this well - the users were already known to the project team in most cases (Bradwell and Marr 2008, 40).

More documentation and dissemination of the processes and findings from co-design projects is needed in order to develop this knowledge. Without it, we cannot hope to provide practice-based evidence to inform the development of public sector capabilities or support different organisations and disciplines to understand and communicate the benefits and risks of co-design (Steen, Manschot, and De Koning 2011, 59-60). As O’Rafferty and colleagues $(2016,16)$ conclude, 'further development of the theoretical and practical framework of co-design for policy and public services is required.' Recognising the yalue of the 'insights of people working on the frontline' and applying theory-based approaches to evaluation could usefully build practice-informed knowledge in this domain (Durose et al. 2017, 136-38). Partnerships between academic researchers and practitioners could help to build a more solid and grounded understanding of co-design for policy.

\section{Conclusion: a call for more research and evaluation on co-design for policy}

Claims abound about the benefits of co-design, yet there is limited evidence of the impacts of

This article is protected by copyright. All rights reserved. 
co-design for developing and implementing public policy. Despite the prevalence of conceptual confusion, limited evidence and likely challenges in practice, this article has nonetheless defined co-design in a way that is appropriate for public policy practitioners and researchers. This definition has been based on both academic and practitioner accounts of co-design, in order to advance practice and research in public administration. The description of the key components of co-design as a process, principles and practical tools, along with the distinctions made between related but not identical concepts, should help researchers and practitioners to identify and analyse examples of co-design in practice. Rather than treating co-design as a buzzword, this categorical definition serves to suggest that if one of these components is missing, then the approach identified cannot justifiably be called co-design.

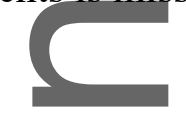

The challenges of the governmental context may make it difficult to achieve the potential outcomes of co-design in practice, yet its radical potential to transform the process and outcomes of policy-making warrants further exploration. As a novel means for creatively engaging citizens and stakeholders to find solutions to complex problems, co-design holds great promise for policy. It may help to generate more innovative ideas, achieve economic efficiencies by improving responsiveness, foster cooperation between different groups, reinvigorate trust between citizens and public servants, and have transformative effects on participants' agency and wellbeing. If a co-design approach can achieve even some of these benefits, then governmental organisations and policy workers should be exploring ways to adoptand embed this practice. It remains unclear, however, whether co-design can feasibly leap from designing programmes and services to developing and implementing public policies. Further research and evaluation is needed to strengthen our understanding of what co-design for policy entails in practice, as well as if, and how, it achieves any of these benefits for participants, policy-makers, and the people they serve.

This article is protected by copyright. All rights reserved. 


\section{References}

Akama, Yoko. 2018. 'Surrendering to the Ocean: Practices of Mindfulness and Presence in Designing'. In Routledge Handbook of Sustainable Design, edited by Rachel Beth Egenhoefer. Routledge.

Akama, Yoko, and Alison Prendiville. 2016. 'Embodying, Enacting and Entangling Design: A Phenomenological View to Co-Designing Services'. Swedish Design Research Journal 8 (1):29-40. https://doi.org/10.3384/svid.2000-964X.13129.

Al-Kodmany, Kheir. 2001. 'Bridging the Gap Between Technical and Local Knowledge: Tools for Promoting Community-Based Planning and Design'. Journal of Architectural and Planning Research 18 (2):110-30.

All, Anissa, Jan Yan Looy, and Elena Patricia Nuñez Castellar. 2013. 'An Evaluation of the Added Value of Co-Design in the Development of an Educational Game for Road Safety Anternational Journal of Game-Based Learning 3 (1):1-17. https://doi,org/10.4018/ijgbl.2013010101.

Ansell, Christopher, Eva Sørensen, and Jacob Torfing. 2017. 'Improving Policy Implementation through Collaborative Policymaking'. Policy \& Politics 45 (3):46786. https://doi.org/10.1332/030557317X14972799760260.

Auckland Co-Design Lab. 2015. 'Home'. Auckland Co-Design Lab. 2015. http://www.aucklandco-lab.nz/. 2016. 'The Case for Change: Driver Licensing Challenge'. Auckland: Auckland Co-Design Lab.

Bason, Christian, and Andrea Schneider. 2014. 'Public Design in Global Perspective: Empirical Trends'. In Design for Policy, edited by Christian Bason, 23-40. Farnham, Surrey, England: Routledge.

Bevir, Mark. 2009. Key Concepts in Governance. London: Sage.

Bijl-Brouwer, Mieke van der. 2016. 'The Challenges of Human-Centred Design in a Public Sector Innovation Context'. In Design Research Society 50th Anniversary Conference. Brighton, UK.

Bracci, Enrico, Mariagrazia Fugini, and Mariafrancesca Sicilia. 2016. 'Co-Production of Public Services: Meaning and Motivations'. In Co-Production in the Public Sector, edited by Mariagrazia Fugini, Enrico Bracci, and Mariafrancesca Sicilia, 1-11. SpringerBriefs in Applied Sciences and Technology. Springer International Publishing. https://doi.org/10.1007/978-3-319-30558-5_3.

Bradwell, Peter, and Sarah Marr. 2008. 'Making the Most of Collaboration: An International Survey of Public Service Co-Design'. London: Demos in association with PwC's Public Sector Research Centre.

Brown, Tim, and Jocelyn Wyatt. 2010. 'Design Thinking for Social Innovation'. Stanford Social Innovation Review, 2010. http://ojs.unbc.ca/index.php/design/article/view/1272.

Burkett, Ingrid. 2012. 'An Introduction to Co-Design'. Knode.

_ 2016. 'Could Prototyping Reduce Risks and Increase the Chance of Success in Policymaking?' presented at the Tacsifest, Melbourne.

Cabinet Office. 2017. 'Open Policy Making Toolkit'. GOV.UK. 3 January 2017. https://www.gov.uk/guidance/open-policy-making-toolkit.

Chen, Dung-Sheng, Cheng Lu-Lin, Caroline Hummels, and Ilpo Koskinen. 2016. 'Social Design: An Introduction'. International Journal of Design 10 (1):1-5.

Christiansen, Jesper. 2016. 'Embedding Design: Towards Cultural Change in Government'. In Service Design Impact Report: Public Sector, edited by Birgit Mager, 48-59. Köln: Service Design Network.

This article is protected by copyright. All rights reserved. 
Cohen, Reuven. 2014. 'Design Thinking: A Unified Framework For Innovation'. Forbes, 31 March 2014.

http://www.forbes.com/sites/reuvencohen/2014/03/31/design-thinking-a-unified-fram ework-for-innovation/.

Colebatch, Hal K. 2005. 'Policy Analysis, Policy Practice and Political Science'. Australian Journal of Public Administration 64 (3):14-23.

Cooke, Maeve. 2000. 'Five Arguments for Deliberative Democracy'. Political Studies 48 (5):947-69. https://doi.org/10.1111/1467-9248.00289.

Department of Health and Human Services. 2016. 'Roadmap for Reform: Strong Families, Safe Chitdren'. Melbourne: State of Victoria. www.dhs.vic.gov.au.

Department of Health and Human Services, and Peer Academy. 2016. 'What Is Co-Design? An Introduction to Co-Design for the Victorian Public Sector'. Version 1. Melbourne: State of Victoria.

Department of Industry, Innovation and Science. 2017. 'Hidden in Plain Sight: Building an Understanding of How the Australian Public Service Can Unlock Community Expertise to Improve Policy, Programmes and Service Delivery'. Discover phase report. Commitment 5.2 of Australia's First Open Government National Action Plan. Canberra. Commonwealth of Australia.

Department of Premier and Cabinet. 2016. 'Ending Family Violence: Victoria's Plan for Change'. State Government of Victoria.

Design Couneil. 2007. 'Eleven Lessons: Managing Design in Eleven Global Brands'. http://www.designcouncil.org.uk/sites/default/files/asset/document/ElevenLessons_D esign_Council $\% 20 \% 282 \% 29$.pdf.

DMA. 2015. Co-Design: 5 Lessons from 5 Projects over 50 Days'. DMA: Connecting Strategies, Services \& People (blog). 23 November 2015. http.//designmanagers.com.au/?p=1451.

Donaldson, David. 2017. 'Govt Co-Design "Not an Equal Partnership": Aboriginal Health CEO'. The Mandarin. 5 June 2017. https://www.themandarin.com.au/79865-govt-co-design-not-equal-partnership-aborigi nal-health-ceo/.

Donetto, Sara, Paola Pierri, Vicki Tsianakas, and Glenn Robert. 2015. 'Experience-Based Co-Design and Healthcare Improvement: Realizing Participatory Design in the Public Sector'. The Design Journal 18 (2):227-48. https://doi.org/10.2752/175630615X14212498964312.

Dorst, Kees. 2010. 'The Nature of Design Thinking'. In Proceedings of the 8th Design Thinking Research Symposium., 131-39. Sydney.

Durose, Catherine, Catherine Needham, Catherine Mangan, and James Rees. 2017. 'Generating “Good Enough" Evidence for Co-Production'. Evidence \& Policy: A Journal of Research, Debate and Practice 13 (1):135-51. https://doi.org/10.1332/174426415X14440619792955.

Durose, Catherine, and Liz Richardson. 2016. Designing Public Policy for Co-Production: Theory, Practice and Change. Bristol: Policy Press.

Edelman. 2017. 2017 Edelman Trust Barometer'. Edelman. 2017. https://www.edelman.com/trust2017/.

Evans, Mark. 2012. 'Department of Education, Employment and Workplace Relations Innovations Fund - An Evaluation'. Canberra: ANZSOG Institute for Governance.

Evans, Mark, and Nina Terrey. 2016. 'Co-Design with Citizens and Stakeholders'. In Evidence-Based Policy Making in the Social Sciences: Methods That Matter, edited by Gerry Stoker and Mark Evans. Bristol: Policy Press.

This article is protected by copyright. All rights reserved. 
Farr, Michelle. 2013. 'Citizens and the Co-Creation of Public Service Innovations'. In Handbook of Innovation in Public Services, edited by Stephen Osborne and Louise Brown, 445-58. Edward Elgar Publishing.

Fischer, Frank. 2009. Democracy and Expertise: Reorienting Policy Inquiry. Oxford: Oxford University Press.

Foa, Roberto Stefan, and Yascha Mounk. 2016. 'The Democratic Disconnect'. Journal of Democracy 27 (3):5-17.

Frontier Economics. 2013. 'Reducing Violence and Aggression in A\&E: Through a Better Experience'. London: Design Council.

http://www.designcouncil.org.uk/sites/default/files/asset/document/AE_evaluation_su mmary 10. .pdf.

Fung, Archon. 2006. 'Varieties of Participation in Complex Governance'. Public Administration Review 66.

Gottweis, Herbert. 2007. 'Rhetoric in Policy Making: Between Logos, Ethos, and Pathos'. In Handbook of Public Policy Analysis: Theory, Politics, and Methods, edited by Frank Fischer, Gerald J. Miller, and Mara S. Sidney, 237-50. Boca Raton, FL: Taylor \& Francis.

Government Economics Network. 2016. 'People-Centred Policy: Through Behavioural Insights, Design Thinking and Better Use of Data'. presented at the Government Economics Network Conference workshops, The Policy Project, Wellington,

\section{December.}

http://www.dpmc.govt.nz/sites/all/files/people-centred-policy-gen-conference-worksh ops-7-dec-2016-v2.pdf.

Hagen, Penny, and Natalie Rowland. 2011. 'Enabling Codesign'. Johnny Holland (blog). 18 November 2011. http://johnnyholland.org/2011/11/enabling-codesign/.

Holmes, Brenton. 2011. 'Citizens' Engagement in Policymaking and the Design of Public Services ${ }^{2}$ Research Paper 1. Parliamentary Library. Canberra: Parliament of Australia. http:/www.aph.gov.au/About_Parliament/Parliamentary_Departments/Parliamentary Library/pubs/rp/rp1112/12rp01.

Howell, Michaela, and Margaret Wilkinson. 2016. 'Policy Design as Co-Design'. In Designing Public Policy for Co-Production, edited by Catherine Durose and Liz Richardson, 15767. Policy Press. https://doi.org/10.1332/policypress/9781447316695.003.0015.

Howlett, Michael, and Andrea Migone. 2013. 'Policy Advice through the Market: The Role of External Consultants in Contemporary Policy Advisory Systems'. Policy and Society $32(3): 241-254$.

IDEO. n.d. Human Centered Design: Toolkit. 2nd ed.

Kaethler, Michael, Seppe De Blust, and Tim Devos. 2017. 'Ambiguity as Agency: Critical Opportunists in the Neoliberal City'. CoDesign 13 (3):175-86.

https://doi.org/10.1080/15710882.2017.1355002.

Kieboom, Marlieke. 2014. Lab Matters: Challenging the Practice of Social Innovation Laboratories. Amsterdam: Kennisland.

Kimbell, Lucy. 2015. Applying Design Approaches to Policy Making: Discovering Policy Lab. Brighton: University of Brighton.

Kimbell, Lucy, and Jocelyn Bailey. 2017. 'Prototyping and the New Spirit of Policy-Making'. CoDesign 13 (3):214-26.

King, Stanley, Merinda Conley, Bill Latimer, and Drew Ferrari. 1989. Co-Design: A Process of Design Participation. New York: Van Nostrand Reinhold.

Larkin, Michael, Zoë V. R. Boden, and Elizabeth Newton. 2015. 'On the Brink of Genuinely Collaborative Care: Experience-Based Co-Design in Mental Health'. Qualitative Health Research 25 (11):1463-76. https://doi.org/10.1177/1049732315576494.

This article is protected by copyright. All rights reserved. 
Lenihan, Don, and Lynelle Briggs. 2011. 'Co-Design: Toward a New Service Vision for Australia'. Public Administration Today 25 (March):35-47.

Locock, Louise, Glenn Robert, Annette Boaz, Sonia Vougioukalou, Caroline Shuldham, Jonathan Fielden, Sue Ziebland, Melanie Gager, Ruth Tollyfield, and John Pearcey. 2014. 'Using a National Archive of Patient Experience Narratives to Promote Local Patient-Centered Quality Improvement: An Ethnographic Process Evaluation of "Accelerated" Experience-Based Co-Design'. Journal of Health Services Research \& Policy 19 (4):200-207. https://doi.org/10.1177/1355819614531565.

MacArthur, Julie L. 2016. 'Challenging Public Engagement: Participation, Deliberation and Power in Renewable Energy Policy'. Journal of Environmental Studies and Sciences 6 (3):631-40. https://doi.org/10.1007/s13412-015-0328-7.

Manzini, Ezio. 2015. Design, When Everybody Designs: An Introduction to Design for Social Innovation. MIT Press.

McGann, Michael, Emma Blomkamp, and Jenny M. Lewis. forthcoming. 'The Rise of Public Sector Innovation Labs: Experiments in Design Thinking for Policy'. Policy Sciences.

Mclaverty, Peter, and Darren Halpin. 2008. 'Deliberative Drift: The Emergence of Deliberation in the Policy Process'. International Political Science Review 29 (2):197214. https://doi.org/10.1177/0192512107085612.

Mintrom, Michael, and Joannah Luetjens. 2016. 'Design Thinking in Policymaking Processes: Opportunities and Challenges'. Australian Journal of Public Administration 75 (3):391-402.

Moore, Tim, Myfanwy McDonald, Harriet McHugh-Dillon, Sue West, Child Family Community Australia, and Australian Institute of Family Studies. 2016. 'Community Engagement: A Key Strategy for Improving Outcomes for Australian Families'. Melbourne, Vic.: Australian Institute of Family Studies.

https://aifs.gov.au/cfca/publications/community-engagement.

Naranjo-Bock, Eatalina. 2012. 'Creativity-Based Research: The Process of Co-Designing with Users'. UX Magazine, 24 April 2012.

https://uxmag.com/articles/creativity-based-research-the-process-of-co-designing-wit h-users.

O'Rafferty, Simon, Adam de Eyto, and Huw J. Lewis. 2016. 'Open Practices: Lessons from Co-Design of Public Services for Behaviour Change'. In Proceedings of DRS 2016:

Design + Research + Society, edited by Peter Lloyd and E Bohemia, 3573-90.

Brighton: Design Research Society.

Palmås, Karl, and Otto von Busch. 2015. 'Quasi-Quisling: Co-Design and the Assembly of Collaborateurs'. CoDesign 11 (3-4):236-49. https://doi.org/10.1080/15710882.2015.1081247.

Palmer, Victoria I, Patty Chondros, Donella Piper, Rosemary Callander, Wayne Weavell, Kali Godbee, Maria Potiriadis, et al. 2015. 'The CORE Study Protocol: A Stepped Wedge Cluster Randomised Controlled Trial to Test a Co-Design Technique to Optimise Psychosocial Recovery Outcomes for People Affected by Mental Illness in the Community Mental Health Setting'. BMJ Open 5 (3):e006688.

https://doi.org/10.1136/bmjopen-2014-006688.

Piper, Donella, Rick Iedema, Jane Gray, Raj Verma, Lee Holmes, and Nicole Manning. 2012. 'Utilizing Experience-Based Co-Design to Improve the Experience of Patients Accessing Emergency Departments in New South Wales Public Hospitals: An Evaluation Study'. Health Services Management Research 25 (4):162-72. https://doi.org/10.1177/0951484812474247.

This article is protected by copyright. All rights reserved. 
Reich, Yoram, Suresh L. Konda, Ira A. Monarch, Sean N. Levy, and Eswaran Subrahmanian. 1996. 'Varieties and Issues of Participation and Design'. Design Studies 17 (2):165-80. https://doi.org/10.1016/0142-694X(95)00000-H.

Roggema, Rob. 2014. 'The Design Charrette'. In The Design Charrette: Ways to Envision Sustainable Futures, edited by Rob Roggema, 15-34.

https://doi.org/10.1007/978-94-007-7031-7_2.

Sanders, Elizabeth. 2008. 'An Evolving Map of Design Practice and Design Research'. Interactions, 1 November 2008.

http://www.dubberly.com/articles/an-evolving-map-of-design-practice-and-design-res earch.htmt.

- 2014. 'Perspectives on Participation in Design'. In Wer gestaltet die Gestaltung?:

Praxis, Theorie und Geschichte des partizipatorischen Designs, edited by Claudia Mareis, Matthias Held, and Gesche Joost, 61-75. transcript Verlag.

Sanders, Elizabeth, and Pieter Jan Stappers. 2008. 'Co-Creation and the New Landscapes of

Design’. CoDesign 4 (1):5-18. https://doi.org/10.1080/15710880701875068.

Sanoff, Henry. 1990. Participatory Design: Theory \& Techniques. Raleigh, N.C: Bookmasters.

Service Design Network. 2016. 'Service Design Impact Report: Public Sector’. Köln: Service Design Network.

http://blog.experientia.com/new-report-service-design-impact-public-sector/.

State Government of Victoria. 2017. 'Support and Safety Hubs: Statewide Concept'. http://apo.org.au/system/files/97056/apo-nid97056-350306.pdf.

Steen, Marc, M. A. J. Manschot, and Nicole De Koning. 2011. 'Benefits of Co-Design in Service Design Projects'. International Journal of Design 5 (2):53-60.

TACSI. 2017. 'The Innovation Age'. The Australian Centre for Social Innovation. 2017. http./tacsi.org.au/project/the-innovation-age/.

Tonurist, Piret, Rainer Kattel, and Veiko Lember. 2015. 'Discovering Innovation Labs in the Public Sector'. 61. Working Papers in Technology Governance and Economic Dynamics. Norway: The Other Canon Foundation. http://hum.ttu.ee/wp/paper61.pdf.

Torjman, Lisa. 2012. 'Labs: Designing the Future'. Ontario: MaRS Discovery District.

Treadwell, Jane. 2013. 'DesignGov Pilot Finishes'. DesignGov (blog). 12 December 2013. https://design.govspace.gov.au/2013/12/12/designgov-pilot-finishes/.

Voorberg, William H., Viktor JJM Bekkers, and Lars G. Tummers. 2015. 'A Systematic Review of Co-Creation and Co-Production: Embarking on the Social Innovation Journey". Public Management Review 17 (9):1333-1357.

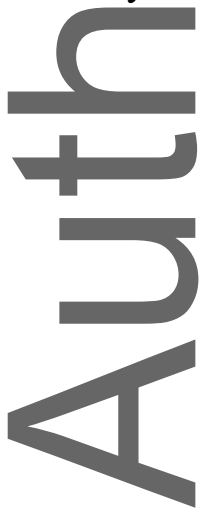

This article is protected by copyright. All rights reserved. 


\section{University Library}

\section{- M M I N E R VA A gateway to Melbourne's research publications}

Minerva Access is the Institutional Repository of The University of Melbourne

Author/s:

Blomkamp, E

Title:

The Promise of Co-Design for Public Policy

Date:

2018

Citation:

Blomkamp, E. (2018). The Promise of Co-Design for Public Policy. Australian Journal of Public Administration, 77 (4), pp.729-743. https://doi.org/10.1111/1467-8500.12310.

Persistent Link:

http://hdl.handle.net/11343/283557 